\section{DROPOUT POLICY IN CZECH HIGHER EDUCATION: CAN UNIVERSITIES SERVE SEVERAL MASTERS?}

\section{Václav Švec, Aleš Vlk and Šimon Stiburek}

Abstract: The purpose of this study is to explore the way higher education institutions adapt to environmental pressures. These pressures can be represented either by various demands or by specific policies. Dropout policy is examined on a Czech case study in order to demonstrate that at the end of the day, higher education institutions respond mainly to the most pressing challenges of an economic nature in the most rational way. As a result, their traditional mission (teaching, research, the third mission), and mainly the social function of the higher education system, may be at stake. At the same time, this study illustrates how difficult it is to introduce any higher education policy without thorough evaluation of other policies in place and of various factors affecting institutional behaviour.

Keywords: Demands, dropout, environmental pressure, higher education policy, organization, social mission, study success, teaching, third mission, university

VÁCLAV ŠVEC - Czech University of Life Science, Prague • svec@pef.czu.cz

ALEŠ VLK - Tertiary Education \& Research Institute, Brno•ales.vlk@teri-institute.eu

ŠIMON STIBUREK - Charles University in Prague • simon.stiburek@gmail.com

\section{Central European Journal of Public Policy}

Vol. 9 - № 1 - May 2015 - pp 126-147

ISSN 1802-4866

O 2015 Václav Švec, Aleš Vlk and Šimon Stiburek

Licensed under Creative Commons Attribution 3.0

\section{INTRODUCTION}

According to Neave, contemporary higher education (HE) is facing an age-old dilemma like the legendary Whitechapel tailor: "Can one have both quality and width and more especially so when more customers want traditional quality and excellence but are no longer prepared to pay the previously going rate?" (Neave, 1994, p. 115). In other words, as we state in the title of our article: Can universi- ties serve several masters? Is it possible for a modern higher education institution (HEI) ${ }^{1}$ surrounded by a rapidly changing environment to fulfil its mission and to meet expectations that are imposed upon it? We try to tackle this complicated and rather ambitious issue only in a particular segment of a university's teaching mission and social function, namely study success and dropout policy $^{2}$.

Our contribution is focused on study success and/or dropout rates and related policies. The relevance of this topic in the European context is stressed by the increasing attention paid to it by the European Commission (EC, 2003a; EC, 2003b; EC, 2005). High dropout and graduate unemployment rates, high failure, excessive duration of studies and low attainment levels are perceived as expenditure inefficiencies. For this reason, the Directorate General of Education and Culture (DG EAC) of the European Commission awarded a research assignment on dropout and completion in higher education (HEDOCE) to a consortium led by the Center for Higher Education Policy Studies (CHEPS) at the University of Twente, the Netherlands, in $2014^{3}$ to conduct a comparative overview of the main policies and measures in 36 countries, including eight indepth case studies.

In the first section of our contribution, a model of organizational behaviour by Bunge (1963) and Pfeffer and Salancik (1978) is used to describe how organizations in general respond to environmental pressure. In our specific case of higher education, such pressure is represented mainly by higher education policies and various demands arising at different levels. A key section of our contribution is devoted to a Czech case study. In the discussion section, we relate some of our findings back to organizational theory. In the concluding section, we present our view on how a contemporary university in the Czech Republic might be able to meet all the expectations, implement various policies, adopt adequate measures and perform well in all its activities.
1 The terms "university" and "higher education institution" (HEI) are used as equivalents in this text. They represent a higher-profile academic organization offering at least bachelor's and master's degrees and involved in research as an integral part of its mission.

2 In our article, dropout policy refers to a policy of reducing the dropout rate or increasing the success rate in higher education.

3 http://www.utwente.nl/bms/cheps/news/CHEPS\%20awarded\%20two\%20new\%20projects\%20 by\%20the\%20European\%20Commission/ 


\section{ORGANIZATIONS UNDER ENVIRONMENTAL PRESSURE}

Higher education institutions (HEIs) represent organizations with a longstanding history of searching for truth and maintaining knowledge (Maassen, 1997) Nowadays, teaching, research and the "third mission"4 are perceived as the core roles of HEIs in the modern society. However, activities contributing to their fulfilment can be compromised by external environmental pressures. For our inquiry into HEIs' organizational responses, we use the following conceptual framework.

All organizations, irrespective of field, exist within their specific environment. Such an environment represents all external forces, factors or conditions that provide resources or pose limitations with some degree of impact on the organization's strategies and managerial decisions. There has been a long-term consensus about these indisputable facts among all authors from the fields of management or organization theory (Hicks \& Gullet, 1976; Mintzberg, Ahlstrand \& Lampel, 1998; Thompson \& Martin, 2005; Mooradian, Matzler \& Ring 2012, etc.)

To describe the general options an organization might choose in responding to external environment, we use the account presented by Bunge (1963) The external environment of an organization provides the inputs: resources, opportunities, and limits that determine the nature and success of the organization. The organization is represented by its own internal environment which from the outside, might look like a "black box". A black box is an object or a system seen in terms of its input and output without any knowledge of its in ternal workings. Here, it refers to detailed information on processes through which institutions and actors affect changes in the organization (Bunge, 1963; Zucker, 1991; Trommel \& Van der Veen, 1997).

An organization can exist when it provides products or services desired by its environment. That means that its activities must be acceptable to the environment as it responds to the organization's outputs. The general options that any organization can choose from, according to the conditions in its external environment, are described in Figure 1.

4 A third mission may include regional involvement, technology transfer, supporting innovation processes and other important roles of universities. Brennan (2002), for example, adds another goal of higher education, which is particularly important for developing countries or countries in goal of higher education, which is particulary im tions.
Figure 1 General responses of any organization to the inputs of the external environment

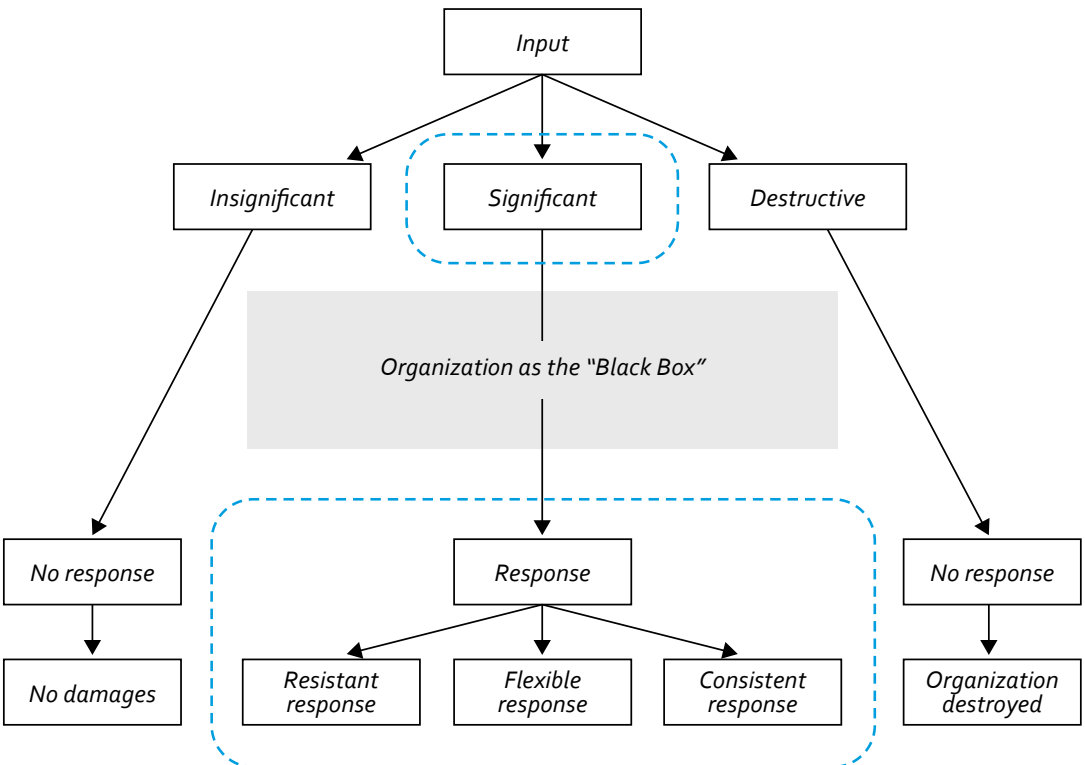

Source: Adapted from Pfeffer and Salancik (1978), Bunge (1963).

We see different external forces, factors and conditions as inputs to the organization's black box. These inputs can be divided into the following categories according to their implications:

1. insignificant, where no action is required from the organization, as this input represents neither an opportunity nor a threat;

2. destructive, where any action is meaningless as whatever the organization does will invariably lead to a downfall; and

3. significant inputs worth reaction.

Pfeffer and Salancik (1978) claim that organizations can adapt and change to fit environmental requirements, or they can attempt to alter the environment so that it fits their capabilities. According to this statement we can classify an organization's responses as follows (ibid.):

1. resistant response, which only preserves the status of the organization;

2. flexible response, where organizations adapt and change to fit the environmental requirements either (a) negatively - the organization leaves the market - or (b) positively - the organization takes the opportunity; and 
3. consistent response, by which the organization creates new needs, activities or products.

The environment in which organizations exist is becoming increasingly turbulent, complex, and fuzzy. According to Oomens and Bosch (1999), "public opin ion and individual norms and values have changed, and society's expectations and the demands it makes to companies are now higher than before. Large organizations are being asked ... to pay considerably more attention to the in terests of various internal and external stakeholders. These self-appointed stakeholders can raise strategic issues which have a serious impact on a company's performance..." (p. 49).

If these issues are not properly addressed and managed, they can escalate and cause damage to the organization. Starbuck (1965) described the scale of such strategic issues: "All aspects of organization which are relevant to adaptation", adding that "one could legitimately discuss everything that has been written about organizations" (p. 468). Mintzberg, Ahlstrand and Lampel (1998) name a number of fields that provide relevant insights into how organizations change: psychology, anthropology, economics, urban planning, military history, and also political science with respect to public policy making.

In our study we analyse policies in the field of higher education and various global demands put on universities as environmental pressures, i.e. external forces, factors or conditions as defined above. The organization which is put under outside pressure here refers to a university located in Europe. As Enders (2011) states: "Nowhere today is higher education undergoing more substantial change than in Europe. As countries pursue policies designed to integrate their economies, political systems and social structures, it is becoming increasingly clear that higher education, research and innovation are critical components to fully realizing the potential gains stemming from the changes ahead" (p. 1).

It must also be stressed that the external forces represented by stakeholders (see, for example, Freeman, 1984; Mitchell, Angle \& Wood, 1997) in higher education are much more complex than in any other sector of our society. The relationship between HEIs, government and other external actors with direct or indirect interest in higher education cannot be looked upon through a simple consumer-provider analogy. It is a complex interactive policy with many different stakeholders participating at various moments and in different ways (Maassen, 2000).

\section{DEMANDS ON HIGHER EDUCATION}

During the last few decades, traditional higher education systems have been under an increasing pressure to meet the demands of society in general. Clark (1997) identifies three major sets of demands on higher education:

1. a demand for greater access to higher education;

2. more qualifications and positions on the labour market require a university degree;

3. governments as well as other stakeholders expect more efficient behaviour of traditional higher education providers; better results should be achieved for less input.

Concerning the increased demand for higher education, Mazzarol and Sou$\operatorname{tar}(2001)$ stress the fact that it has also been driven by the expectation that a higher degree would advance the social and economic status of a graduate. Also, the demand of higher efficiency has not evolved overnight. An important shift started to take place in the mid-1980s as governments made an effort to reduce public expenditures. Concepts such as output, productivity and costs were introduced into academia (Neave, 1994).

Van der Wende (2003) distinguishes between two main global demands in the higher education context. The first is caused by the need for wider access to higher education. The number of higher education students worldwide was predicted to grow from 97 million in 2000 to 263 million in 2025 (Böhm et al., 2002). The second global trend can be associated with the transition from postindustrial to knowledge economies, combined in Western countries with an aging population. More diversified and flexible modes of providing higher education are needed, including lifelong learning, corporate training, etc.

In the European context, there are also specific factors related to the European Communities and later to the European Union (EU). Higher education has been paid increasing attention by the European Commission as a tool to facilitate European integration (Neave, 1995). Since the late 1990s, two major developments have been shaping reforms in European higher education systems. First the Bologna declaration (1999) followed by the Bologna process, and second the EU's Lisbon Strategy (2000) aimed at making HE systems part of knowledge-based economies (Enders et al., 2011).

Higher education institutions have been increasingly in the focus of initiatives at the EU level. Van Vught (2011) identifies the following issues which are most likely to affect the higher education policies and agendas of European institutions in the near future:

- enrolments and labour market needs: to produce sufficient numbers of qualified professionals for the labour market; 
- research excellence and knowledge transfer: to achieve world-class research excellence by strengthening the research base;

- public and private funding: to increase private resources in education and research by introducing tuition fees and closer cooperation with business and industry, including the knowledge transfer process;

- multi-level governance: to shape HE institutions profiles and positions toward academic stratification and regional differentiation.

As a result of various external factors, including policies at the national and EU levels, a modern university located in Europe nowadays is facing at least the following challenges:

- to absorb an increasing number of students while the student body becomes more and more heterogeneous in terms of background, abilities and expectations;

- to maintain the social function of HE in society;

- to keep the quality of teaching.

- to attract more fee-paying international students in order to compensate for the decline of domestic student body;

- to meet the rapidly changing requirements of employees;

- to achieve excellence in research

- to increase knowledge transfer and commercialization of research outputs;

- to demonstrate efficiency.

With respect to the focus of our contribution, we are mainly interested in the first three points of the list, which are closely interconnected (absorption, social function and quality of teaching). These challenges are related to teaching performance of higher education institutions, which - according to Cave (1997) - can be measured by five different ways: value-added measures, cost measures, first destination of graduates on the labour market (employability), student and peer evaluations, and wastage and completion rates. In our case, we choose the latter two rates ${ }^{5}$ in order to estimate how successful a higher education institution is in meeting its objectives with respect to teaching and the third mission.

Dropout and study success are becoming the key issues to be addressed in order to effectively increase the number of college-educated people in the society and ensure vertical social mobility. As many authors state, student dropout is significant to higher education systems around the world. Mantz and Ber-

5 We use the term "dropout" instead of "wastage" in our article (many authors also use terms such as attrition, mortality, dismissal, withdrawal or stopout). Furthermore, we prefer the "study success" from "completion rate" The term "retention" is also used to refer to the ability "of $\mathrm{HE}$ institutions to keep students from their entry until their graduation. Other synonym in the literature include persistence, students' success, completion or graduation. nard (2004) explain a dropout policy as a tool focusing on the effectiveness and efficiency of an institution or a system of higher education. Wild and Ebbers (2002) support this statement as they see dropout rates as important measures of institutional effectiveness with a broader impact to relevant stakeholders in the higher education system - internal administrators, academic staff taxpayers, legislators, public policy makers, etc. Brunsden et al. (2000) see dropout policy as a complex issue affecting the different personal, institutional, and societal aspects of higher education, each with its costs and implications to all stakeholders. Ozga and Sukhnandan (2004) argue the importance of dropout in economic terms - they see it as:

- a waste of university resources which are limited

- damage to the institution's reputation

a negative long-term influence on attracting new students.

Mantz and Bernard (2004) see the dropout policy in higher education as very important from the governmental perspective, mainly for labour market and public spending considerations.

On one hand, there is a pressure to widen access as part of the social function of higher education in the society. On the other hand, due to the increasingly heterogeneous student body with respect to background, abilities and expectation, a rather significant dropout rate has been observed across EU countries.

We can conclude that the dropout issue has been paid growing attention with respect to its conceptualization in HE literature as well as at the EU level. Through the following Czech case study we would like to take a closer look at the national and institutional level to see whether at all, or how, policies to combat dropout have been implemented, whether there are any policy deficits in this area and possibly what their causes are.

\section{METHODOLOGY}

The case study was carried out in 2014 within the framework of the abovementioned pan-European study on dropout and completion in higher education (HEDOCE) assigned by the European Commission. The two major deliverables of the study were:

1. a comparative overview of the main policies and measures related to reducing dropout rates and increasing completion rates in each of the 36 countries covered by the study;

2. eight national case studies analysing the relationship between the national policies and measures in place and system performance. 
The Czech case study was based on desk research (various documents at the national and institutional levels), expert interviews and focus groups with various stakeholders. At the national level, actors from the following institutions were approached: the Ministry of Education, the Accreditation Commission (an external quality assurance agency), the Higher Education Council and its Student Chamber, the Czech Rectors' Conference, the Parliament of the Czech Republic, and selected experts in the field of higher education.

Furthermore, two Czech public universities were selected in order to gain more insight into the institutional policies on study success and the ways national policies affect institutional behaviour and policy implementation. Expert interviews and focus groups were conducted with university and faculty man agement, student support units, teachers and students. Both of the institutions selected are medium-sized universities (10,000 to 25,000 students) with multiple faculties offering programs in a broad range of disciplines. One is located in Prague and the other one, with a clear regional profile, is located in a smaller city.

Altogether, the authors conducted eight interviews and one focus group with national-level actors, representatives and experts, and ten interviews and three focus groups at the level of HEIs. The average length of an interview was close to one hour

Regarding the dropout policies, the only publicly available source of information at the moment are the annual reports of individual HEIs, which should contain - according to the structure recommended by the Ministry of Education, Youth and Sports (MEYS) - at least an elementary overview of dropout data and a list of measures adopted by the institution to improve study success

The data on dropout and completion rates were retrieved from the national student register ${ }^{6}$. In accordance with applicable laws, every HEI is obliged to keep a student database for budgetary and statistical purposes. The national student register contains the data from individual institutional databases on students enrolled at various programs at the bachelor, master or doctoral levels. The data is not publicly available, but the authors were able to work with the data in their research study. Due to privacy concerns, only aggregated data were available for the analysis, which limited the scope of methods applicable.

Some major limitations of the case study presented should be outlined at this stage. First, the study itself was focused primarily on the policies implemented at either the national or the institutional levels. Therefore, data was not gathered on questions at the level of individual students including their reasons for discontinuation of studies. Second, only public higher education in stitutions were taken into account; they constitute a major part of the system

6 Sdružené informace matrik studentů (SIMS). representing around 88 percent of the total student population. Third, only two in-depth case studies were conducted and they could not cover all the different programs and disciplines. Yet to minimize this handicap, intensive analyses of other institutions' documents were conducted. Fourth, the study was focused mainly on the first two academic levels - bachelor and master degree programmes. Only limited attention was paid to doctoral (PhD) programmes, partly due to the different status of $\mathrm{PhD}$ students in various EU countries. It must be stressed that a low completion rate in doctoral programmes is viewed as problematic, yet the underlying reasons might be partly different from the lower-level programmes.

\section{CASE STUDY: THE CZECH REPUBLIC}

\section{Dropout research and policy}

Research on students' dropout and study success is not fully developed in the Czech Republic. There are few papers or studies dealing with dropout and retention policy in higher education.

Menclová et al. (2004) discuss the failure rate of freshmen in engineering programs. Matějů et al. (2004) look at freshmen at all universities in the Czech Republic, while Mouralová and Tomášková (2007) focus on the causes of failure at Czech universities in general. All these studies show some important reasons of dropout: student dissatisfaction with the form of teaching or with the field of study, a discrepancy between the system of study at secondary school and university, lack of skills among students, etc.

Beneš and Závada (2009) found differences in students' success rates across programs, with the lowest rate in bachelor programs. Kleňhová and Vojtěch (2011) describe study success across selected fields of higher education. Finally, Fučík and Slepičková (2014) recently analysed the reasons for dropout through a quantitative study conducted at a Czech university, concluding that program-switching and role conflict (family, employment) were the driving forces behind most of the of the dropout decisions observed.

As these studies show, dropout and study success, their causes and consequences, and their relationship with other policies and measures represent a rather complex issue which has been explored only to a limited extent in the context of Czech higher education so far. Dropout policy has neither been addressed from the institutional point of view, nor has a robust quantitative dataset been gathered from the student register and interpreted. The aim of this study is thus also to contribute to research in this field. 
Specifically in relation to study success, the goal of reducing the dropout rates has been stated repeatedly by the MEYS. Already in the HE Strategic Plan for 2000-2005, dropout was presented as a problem and individual reorientation was proposed as the solution: the plan sought to "accommodate all students in case their first choice was not optimal and allow them to reach qualification adequate to their competence by changing their educational pathway." Inefficiency due to dropout was mentioned as well, both for the government (in economic terms) and the student (MEYS, 2000).

As mentioned above, together with other requirements, HEIs are asked to publish in their annual reports elementary dropout data and measures taken to reduce the rates. However, the report structure set by the MEYS is not obligatory, and no shared definitions of dropout are set for this purpose.

The newly adopted Strategic Plan for 2016-2020 sets improving study success as one of the strategic indicators for "Priority Goal 2: Access and Diversity". The target of the Ministry is for 60\% of bachelor's studies started in 2015 to be completed successfully by 2020 (MEYS, 2015). As far as the number is concerned, the dropout rates at Czech public HEIs increased steadily over the last decade, in particular in bachelor's programs.

Graph 1 Cumulative dropout rate in Czech public HEls (students admitted from 2003 to 2013

$60 \%$

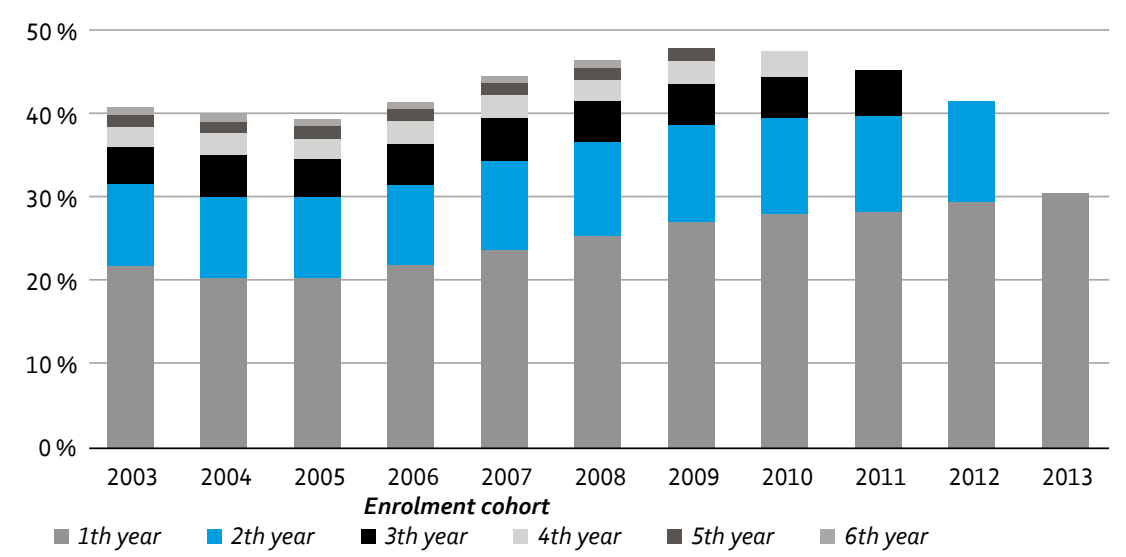

Legend: Cumulative dropout rate in full-time undergraduate (3-4 years bachelor's) and "long cycle" (4-6 years integrated master's) programs at Czech public HEls for studies started from 2003 to 2013. The column always represents one cohort of students based on the year when they stared started their studies. "Year 1" stands for the dropout in the first year of studies (typically after the exam periods of the first or second semesters) and so on. There are only very few students who drop out after the fifth year of studies, so these are not displayed here. Source of data: MEYS, national student register.

Out of the 111,831 students who started their bachelor studies in 2009, $\mathbf{4 1 . 8}$ percent successfully graduated within the prescribed period of studies extended by one year. The trend seems to continue as among students entering bachelor programs in 2013 around 34 percent dropped out after the first year.

Significant differences can be seen among individual disciplines ${ }^{7}$ and institutions and their parts (faculties). Graph 2 shows the cumulative dropout rate for master's programs in the third year of study for the student cohort entering HE in 2008. For bachelor programs started in 2009 (see above), the numbers vary from 8.6 percent at a certain faculty of mechanical engineering and 87.9 percent at a regional faculty of health care. A success rate higher than 70 percent can be observed almost exclusively in the fields of medicine and arts. Graph 3 shows the cumulative dropout rate in the third year of full-time undergraduate programs (bachelor and integrated master's) by major disciplines from 2003 to 2001

Graph 2 Cumulative dropout rate in the $3^{\text {rd }}$ year (master's programs)

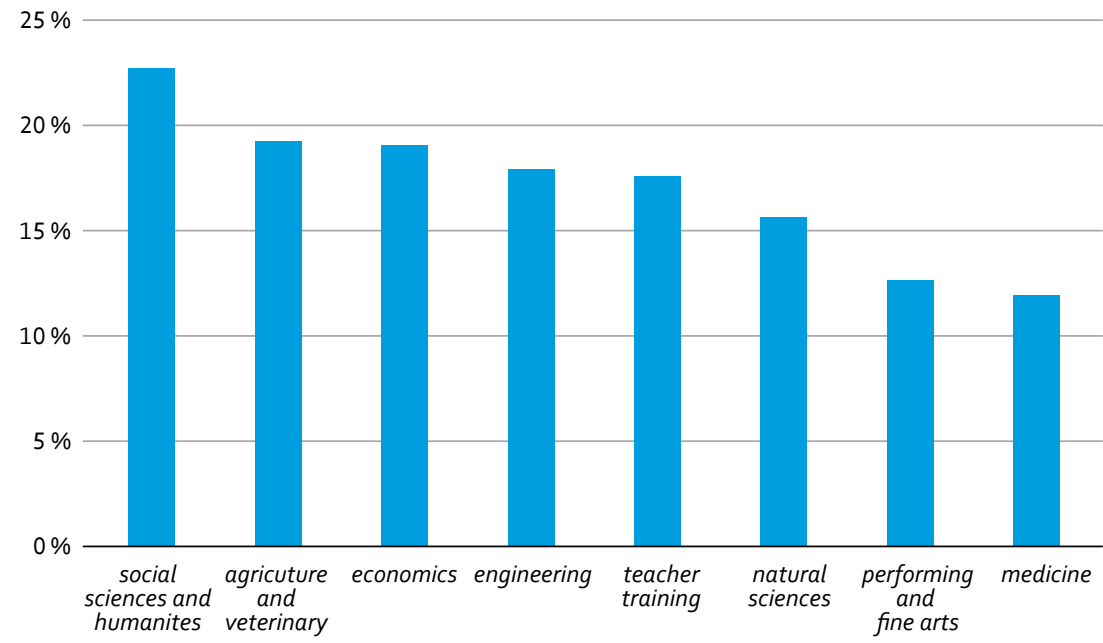

Legend: Cumulative dropout rate in the 3rd year by major disciplines in master's programs. Source of data: MEYS, national student register.

7 The terms "discipline" and "field of studies" are used as equivalents in this article. 
Graph 3 Cumulative dropout rate in the 3rd year (bachelor's and integrated master's programs)
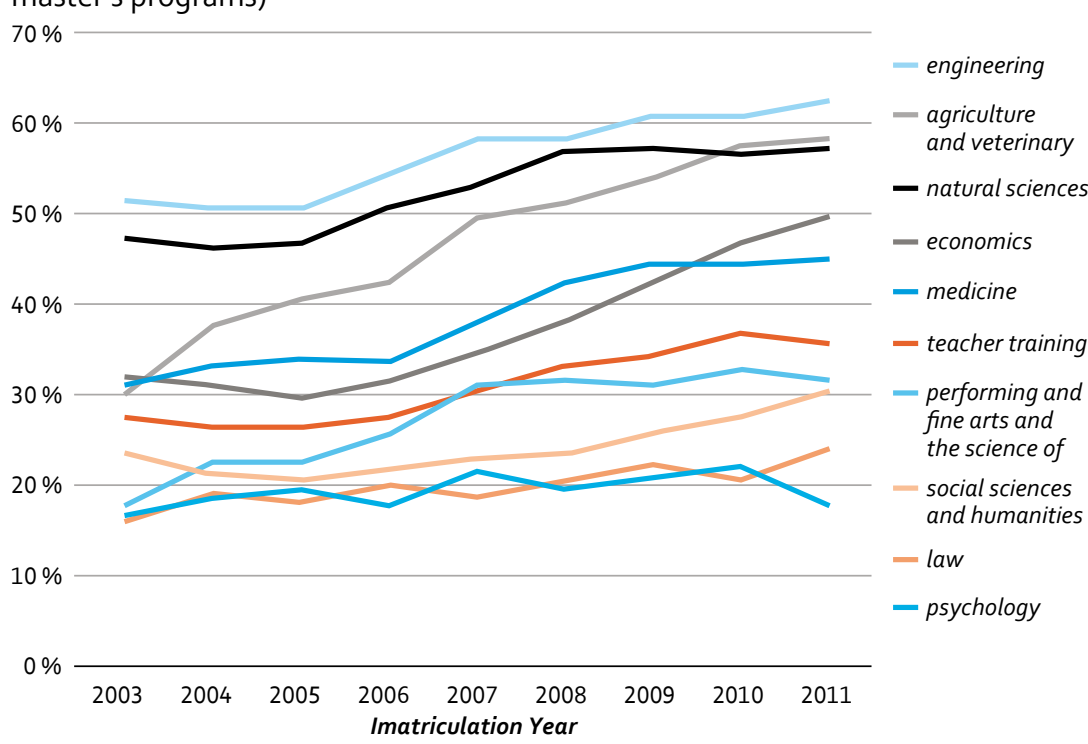

Legend: Cumulative dropout in the 3rd year of full-time undergraduate and "long cycle" (integrated masters) programs at Czech public HEls for studies started from 2003 to 2011 by major disciplines. Source of data: MEYS, national student register.

\section{Context and environmental pressures}

In the following part, we introduce the context of the Czech case study in terms of selected environmental pressures (including external factors and national policies) that seem to affect a large part of the institutional behaviour of Czech universities. During our field research, all relevant stakeholders confirmed that two factors are always taken into account before almost any step at the institutional level is taken: the funding mechanism and the accreditation/reaccreditation criteria for degree programs.

Since the 1990's, the funding of HEIs has been based predominantly on the number of students and their respective study fields (with bonuses for specific programmes such as engineering, natural sciences, medicine or fine and performing arts). Starting from 2010, elements of "quality-based" funding were introduced to reflect research performance, student international mobility and unemployment rates of graduates. The ratio between the per-capita versus the quality-based elements is 76:24 for 2015, with the latter element growing steadily since its introduction. ${ }^{8}$

Caps are another aspect of the funding mechanism that may affect institutional behaviour. Every year, MEYS sets limits for the state-funded study places for each institution, separately in four categories: B1 (first-year bachelor), M1 (first-year integrated master's), N1 (first-year master's), P1 (first-year doctoral) and SP2+ (all other students). HEIs are allowed to admit students over the limit, but these are not funded. Besides the fact that the number of firstyear dropouts is reflected in the SP2+ cap other developments are also considered important. First, the MEYS reflects the demographic decline in the B1 and M1 limits and reduces them every year. Second, it attempts to reduce the share of bachelor-level graduates who continue in a master's programme ${ }^{9}$ by reducing the N1 limits every year as well.

The current accreditation process, which also serves as the main tool of external quality assurance in Czech HE, reflects the quality of teaching only to a limited extent. The main criteria for accreditation and reaccreditation of a degree program relate to the qualification structure of teaching staff ${ }^{10}$ and their research performance. Student services and counselling, the content and form of courses as well as the quality of teaching and learning as such are evaluated less thoroughly, and no site visits take place in the process. ${ }^{11}$

There is also a tendency to dedicate more resources to research and less to teaching. The reasons are of an economic nature, as publication performance is reflected not only in research \& development (R \& D) funding, but also in HE funding. It must be stressed that research grants often constitute a very significant part of institutional budgets. Also, significant research performance is required as part of the sustainability criteria of R \& D centres co-financed by the European Regional Development Fund (ERDF) in the 2007-2013 programming period. Out of the 48 research centres financed, 28 are located at public universities ${ }^{12}$.

Finally, the most important pressure is an external and independent one. The Czech Republic has been facing an enormous demographic decline. The

8 MEYS, http://www.msmt.cz/vzdelavani/vysoke-skolstvi/financovani-vysokych-skol-1

9 This proportion is relatively high in the Czech Republic - in 2012, 64\% of bachelor's level graduates enrolled immediately in a master's degree programme. In 2007-2009, this rate was $72 \%$. The target of the HE Strategic Plan for 2011-2015 was set at 50\% in 2015 (Ministry of Education, Youth and Sports, 2010)

10 In the Czech Republic, the academic ranks of "docent" (assistant professor) and professor are awarded based on set criteria which should ensure comparability across institutions. Research performance is the main criterion in both cases.

11 A revision of the accreditation process and related criteria is expected with the amendment of the Higher Education Act in 2015.

12 For more information, please see: http://www.opvavpi.cz/ 
number of 19-year-olds (and high school graduates) stayed relatively stable over the 2000's but starting from 2011, its decline became one of the biggest challenges for Czech higher education institutions.

\section{Graph 4 Number of 19-year-olds in 1990-2020} Number of 19 years olds in Czech Republic (history and prediction) 1990 - 2020

200000

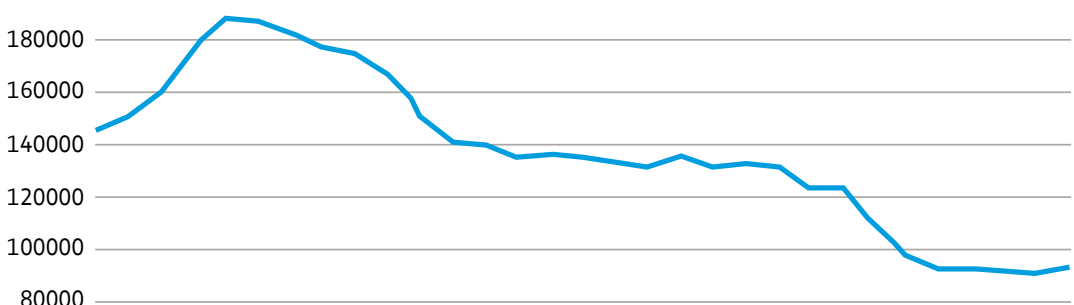

60000

40000

20000

$199019921994199619982000200220042006200820102012 \quad 2014201620182020$ Source of data: Czech Statistical Office.

\section{Findings of the case study}

Although only two institutions were selected for a detailed case study, the authors believe that the observations are relevant and correct. Desk research, interviews with relevant stakeholders as well as experience of individual team members have contributed to selected findings despite the methodological limitations.

To enrol more students in order to increase institutional funding via percapita payments has been the most common response to the environmental pressure. Over the past two decades, most institutions have opted for a steep quantitative growth of students.

As a consequence of the two major parallel developments (increasing enrolment \& demographic decline), a growing proportion of applicants admitted to higher education institutions has been observed during the last couple of years (see Graph 5).
Graph 5 Share of applicants admitted to public HEls (Czech nationals only, 1999-2013)

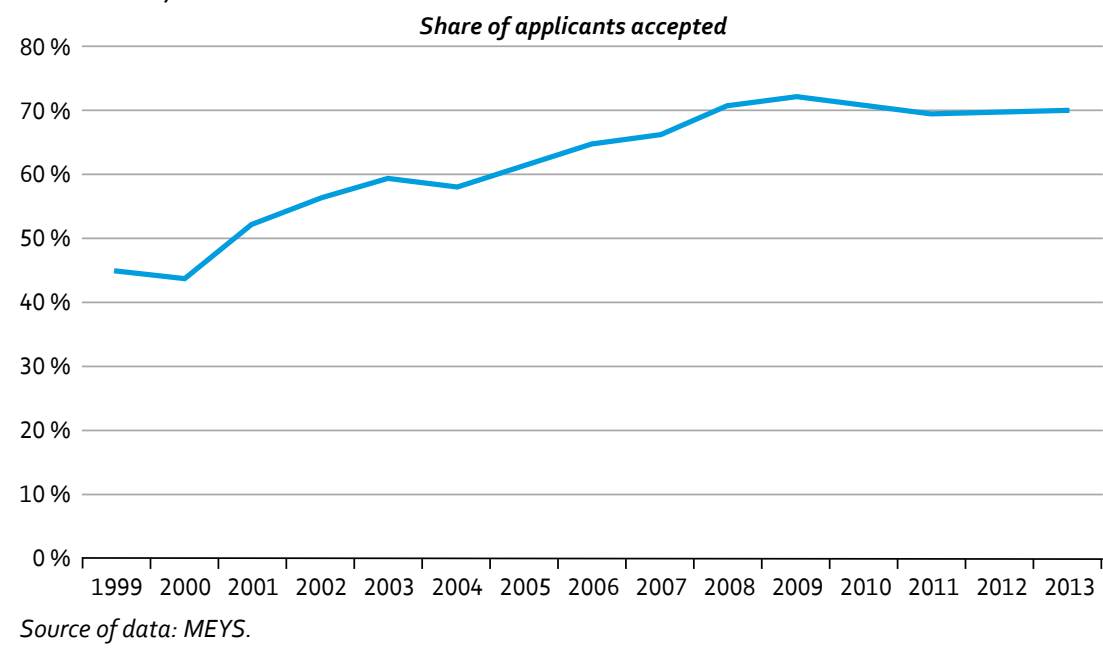
Source of data: MEYS.

In recent years, one strategic approach is clearly common for most of the HEIs and faculties: they have invested much more resources to marketing than ever before in order to attract applicants. Even before the demographic decline, HEIs started to implement a broad range of measures in order to attract, motivate and integrate students in higher quantity as well as "quality" (in terms of competences and attitudes). This includes outreach visits at high schools, cooperation with career counsellors, special web pages for applicants, social media presence, advertising and other tools. Besides increasing the amounts of applicants, these measures are also supposed to prevent dropout.

In many programmes the admission criteria have been eased. In fact, numerous institutions and faculties decided to admit almost anyone who applies, developing or continuing "extended admission process policies" where admission criteria are replaced by first-year courses and exams. This strategy concerns mainly engineering - mechanical, electrical - or chemistry.

Many faculties have reviewed their internal study regulations, easing the criteria for re-enrolment to allow students to stay longer. In some cases, recognition of prior learning has become a routine part of educational pathways, stimulating students to disenrol and reenrol while transferring credits between programmes. Again, that applies mainly to engineering fields.

Besides these general approaches there are other institutional policies and measures adopted by universities or faculties in the recent years in order to 
improve study success. The measures are ordered from the most to the least commonly occurring in our case study:

- developing student services and counselling;

- developing targeted support for special-needs (disabled) students;

- stimulating motivation of students by merit-based scholarships;

- introducing compensatory courses - both extra-curricular (subject to fees) and as part of the program (electives);

- offering educational resources (books, presentations, sometimes also lecture records) online for all students to reduce the barriers to learning;

- re-introducing obligatory attendance at seminars and some courses, namely for freshmen;

- distributing grading deadlines more evenly across the semester and academic year (midterm tests, seminar papers and presentations, etc.) as well as across the entire program (demanding theoretical courses should not be concentrated in the first year only);

- dedicating more attention to student evaluations and opinion surveys to identify trouble points in the student pathway (courses with enormous demands, poor-quality lectures or a disengaging approach of teachers);

- ensuring that the curriculum is up-to-date, in line with industry needs and clearly career-oriented;

- increasing the number of consultation hours of the academic staff;

- establishing off-campus counselling centres in other cities for students in distant learning programs.

\section{DISCUSSION}

Based upon the results of our research, we conclude that dropout is not perceived as a major issue to be addressed in the Czech higher education system On the contrary: it is seen - by the majority of stakeholders as well as the general public - as an embedded part of the system playing the role of a quality watchdog. The most important inputs are those of an economic nature. For any HEI it is above all the number of students that secures institutional funding through the per-capita formula.

Using Pfeffer and Salancik (1978) and Bunge (1963) concepts we can say that demographic decline and funding policy are the significant inputs worth reaction. In order to secure a minimum number of funded students, the institution have implemented various measures including those reducing the dropout rate.

In our case, we observe that HEIs behave indeed highly rationally and formulate their organizational strategies and managerial decisions in line with the theoretical model outlined. In order to stay in the market, they respond only to significant inputs, either through resistance or flexibility. In the Czech environment, it seems to be dominantly the resistant response by which HEIs preserve their status (Pfeffer \& Salancik, 1978). Although rare, there are some examples of flexible responses - setting up international programs in order to attract more fee-paying students, offering more interdisciplinary programs, etc.

In general, the dropout issue alone is considered an insignificant input in Czech higher education. Under certain conditions, no response would be required. However, in combination with other significant inputs (mainly the major demographic decline, the increased share of applicants admitted, the funding system, and the accreditation criteria), it requires an appropriate response. At the same time, the time coincidence of these four inputs made mainly the engineering and partly natural sciences programmes act with utmost urgency. They gradually started implementing various measures to reduce the dropout rate in the absence of any dropout policy at the national level. For them it was a matter of institutional survival under the existing conditions. We also argue that the main rationale behind the above-mentioned measures to increase study success was an economic one - to secure resources for basic activities in a way which is allowed by the regulatory framework. The student-centred approach - e.g., the university should use any available measure in order to help students handle their study load - is only peripheral to most Czech higher education institutions, except those which still keep highly rigorous and multilevel admission exams.

At the same time, we have to state that HEIs are not homogenous in their response to the dropout issue. Individual faculties adopt their own strategies, and even if there is a university-level initiative, the implementation is left to the faculty level (or even to individual departments). It seems that field of study is one of the most relevant factors (variables) impacting the approach towards dropout. The fields most affected by the demographic decline have adopted the most active strategies. They include mechanical and electrical engineering and chemistry. A better situation is faced by civil engineering and natural sciences (biology etc.). An increasing tension can be observed in social sciences (mainly economics or management) where programs are offered also by private higher education institutions. On the other side of the spectrum we can locate highly specialized institutions with a limited number of students and a rather individual approach such as arts.

In terms of public policy and the impact of the European (supranational) level on the national level, it is interesting to see whether the EU's concern about the dropout rate extends in any way beyond the traditional rhetoric. Similarly to other cases, EU pressure has been imposed in a somewhat indirect way. The issue was specifically problematised in the Higher Education Frame- 
work for 2014-2020, which should serve as a background document for European Structural and Investment Funds (ESIF) funding which covers 85 percent of expenditure from the EU budget.

One can agree that a certain minimum dropout rate ${ }^{13}$ is inevitable in any educational process - or even at any human activity. The European Commission was concerned with an average dropout of $40 \%$ at the EU level (EC 2003b) and about inefficiencies (EC, 2003a). Nevertheless, in the case of Czech higher education, the numbers are even more alarming, exceeding $80 \%$ in specific disciplines (or more accurately, programs) such as mechanical engineering. For example, out of 1,000 students admitted to the program in 2008 only 150 were awarded a bachelor degree within five years!

In this respect, we agree that dropout can be seen as inefficiency not only at the institutional level (Ozga \& Sukhnandan, 2004), but also from a governmental perspective (Mantz \& Bernard, 2004). In case the dropout rate reaches a critical level, we support the view of Brunsdens et al. (2000) that the dropout policy affects every aspect of higher education. In our case we even argue that the traditional social mission of higher education is at stake. On the other hand, as is clear from our Czech case study, we cannot directly link the dropout rate with the quality of teaching, inefficiency or any other institutional qualities. The dropout rate should be rather looked upon as a result of other environmental pressures and the setting of the entire system. It cannot be regarded as an isolated phenomenon without taking into account other factors, mainly systemic ones.

\section{CONCLUSIONS}

In our view it seems increasingly difficult for a higher education institution in the Czech Republic to fulfil its mission and the expectations it is exposed to. Furthermore, emerging demands - including policies formulated at both the national and the EU levels - do not always seem to complement one another. The opposite is often the case. While one policy explicitly problematises the dropout issue (however, only in the form of a soft proclamation and rather insignificant measures), another policy (the financing formula and the quality assurance system) in fact forces the institutions to continue their existing pattern of behaviour

Furthermore, it is very difficult for a HEI to meet all the expectations in an environment which reflect the past rather than present or future needs of the

13 It must be stressed that many authors calculate the dropout rate differently. There is no universal methodology employed across higher education literature. society. While the current Czech system is arguably transitioning from a mass system into a universal one ${ }^{14}$ higher education is still considered to be an elite good by the majority of actors as well as the public. The shared view on dropout may also support such a claim. Also the existing structure of the system is still similar to that designed for elite higher education. For example, File et al. (2006) in an OECD Country Note states that the "public university sector is formally undifferentiated, driven by a traditional Humboldtian vision, highly autonomous, self-governing and characterized by strenuous academic career requirements" (p. 16). Since the report was published, however, no fundamental changes have been undertaken in line with its recommendations, despite rather rich publicity and resources devoted to a "tertiary education reform".

We also argue that not seeing a complex picture and/or not anticipating institutional behaviour in the most rational way might constitute a major barrier to implementing any policy. No matter how essential and relevant a certain issue might seem, it must be scrutinized very carefully with respect to any policy being implemented. By concentrating on the dropout issue we try to demonstrate that the entire structure and internal diversification of the higher education system as well as other policies in place should be thoroughly evaluated before any dropout policy is imposed on higher education institutions. Otherwise, successful implementation is at stake.

Finally, we believe that our contribution complements the existing body of research devoted to the dropout issue. However, we still think that further research is needed, both in quantitative and qualitative terms. A very detailed and comprehensive database (the national student register) is available for further analysis. However, any quantitative inquiry should be accompanied by a qualitative survey on major factors influencing students across various disciplines in their decisions to change their field of study or leave the system at all.

\section{REFERENCES}

Beneš, J., \& Závada, J. (2009). New Degree Structure in Higher Education from the Viewpoint of Quantitative Data. Andragogická revue, 1(1), 80-98.

Böhm, A., Davis, D., Meares, D., \& Pearce, D. (2002). Global Student Mobility: Forecasts of the Global Demand for International Higher Education. Sydney, Australia: IDP Education Australia Limited.

Brennan, J. (2002). Transformation of reproduction? In J. Enders \& O. Fulton (Eds.), Education in a Globalising World (pp. 73-86). Dordrecht: Kluwer Academic Publishers.

14 One usually refers to mass higher education when it includes at least 15 percent of the relevan age cohort and to universal $\mathrm{HI}$ when at least 50 percent of the age cohort participates (Trow, 1972). HE in Western Europe reached the mass status in the 1970s and certain countries (among them France, Germany and Italy) achieved universal access 20 years later (Neave, 1994). 
Brunsden, V., Davies, M., Shevlin, M., \& Bracken, M. (2000). Why do HE Students Drop Out? A test of Tinto's Model. Journal of Further and Higher Education, 24(1), 301-310. Bunge, M. (1963). A general black-box theory. Philosophy of Science, 30(4), 364-358. Cave, M. (1997). The use of performance indicators in higher education. A critical analysis of developing practice. London: Kingsley.

Clark, B. R. (1997). Common problems and adaptive responses in the universities of the world: organizing for change. Higher Education Policy, 10(3/4), 291-295

Enders, J. et al. (Eds). (2011). Reform of Higher Education in Europe. Rotterdam: Sense Publishers.

European Commission. (2003a). Investing efficiently in education and training: an imperative for Europe. COM (2002) 779 final. Brussels: EC.

European Commission. (2003b). The role of universities in the Europe of knowledge. COM (2003) 58 final. Brussels: EC.

European Commission. (2005). Mobilising the brainpower of Europe: enabling universities to make their full contribution to the Lisbon Strategy. COM (2005) 152 final. Brussels: EC.

File, J. et al. (2006). OECD country note Czech Republic. Paris: OECD.

Freeman, R. E. (1984). Strategic Management: A stakeholder approach. Boston: Pitman

Fučík, P., \& Slepičková, L. (2014). Studenti, kteří odcházejí: Kvantitativní analýza nedokončených vysokoškolských studií. Aula, 22(1), 24-54

Hicks, H. G., \& Gullet, C. R. (1976). The Management of Organizations. U.S.: McGraw-Hill, Inc.

Kleňhová, M., \& Vojtěch, J. (2011). Úspěšnost absolventů středních škol ve vysokoškolském studiu, předčasné odchody ze vzdělávání. Praha: Národní ústav pro vzděláváni. Retrieved from: http://www.nuov.cz/uploads/Vzdelavani_a TP/VS predcasne odchody_2011_pro_www.pdf

Maassen, P. A. M. (1997). Quality in European Higher Education: recent trends and their historical roots, European Journal of Education, 32(2), 111-127.

Maassen, P. A. M. (2000). Editorial. European Journal of Education, 4, 377-383.

Mantz, Y., \& Bernard, L. (2004). Retention and Student Success in Higher Education, UK: Open University Press.

Matějư, P., Simonová, N., \& Straková, J. (2004). Studium na vysoké škole 2004 Zpráva z výzkumu studentů prvních ročníků vysokých škol v České republice. Praha: Sociologický ústav AV ČR. Retrieved from: http://www.stratif. $\mathrm{cz} /$ ?operation=display\&id $=92$

Mazzarol, T., \& Soutar, G. N. (2001). The Global Market For Higher Education. Cheltenham UK: Edward Elgar Publishing Limited.

Menclová, L., Baštová, J., \& Kronrádová, K. (2004). Neúspěšnost studia posluchaču 1. ročníků technických studijních programů veřejných vysokých škol v ČR a jeji příčiny. Praha: CSVŠ.

Ministry of Education, Youth and Sports. (2000). Dlouhodobý záměr vzdělávací a vědecké, výzkumné, vývojové, umělecké a další tvưrčí činnosti pro oblast vysokých škol na období 2000-2005. Retrieved from: http://www.msmt.cz/vzdelavani/vysoke-skolstvi/ dlouhodoby-zamer-ministerstva

Ministry of Education, Youth and Sports. (2010). Dlouhodobý záměr vzdělávací a vědecké, výzkumné, vývojové, umělecké a další tvưrčí činnosti pro oblast vysokých škol na období 2011-2015. Retrieved from: http://www.msmt.cz/vzdelavani/vysoke-skolstvi/ dlouhodoby-zamer-vzdelavaci-a-vedecke-vyzkumne-vyvojove-a

Ministry of Education, Youth and Sports. (2015). Dlouhodobý záměr vzdělávací a vědecké výzkumné, vývojové, umělecké a dalši tvưrči činnosti pro oblast vysokých škol na období 2016-2020.

Mintzberg, H., Ahlstrand, B., \& Lampel, J. (1998). Strategy Safari: A Guided Tour Through the Wilds of Strategic Management. New York: Prentice Hall.

Mitchell, R. K., Agle, B. R., \& Wood, D. J. (1997). Toward a theory of stakeholde identification and salience: Defining the principle of who and what really counts. Academy of Management Review, 22(4), 853-886.

Mooradian, T. A., Matzler, K., \& Ring, L. J. (2012). Strategic Marketing. New Jersey: Pearson Education, Inc.

Mouralová, M., \& Tomášková, A. Studijní neúspěšnost na českých vysokých školách (a důvody, které k ní vedou). Aula. 2007, 16, 16-26. Retrieved from: http://www.csvs.cz/ aula/clanky/03-2007-1-studijni-neuspesnost.pdf

Neave, G. (1994). The Politics of Quality: developments in higher education in Western Europe 1992-1994. European Journal of Education, 29(2), 115-134.

Neave, G. (1995). On Living in Interesting Times: higher education in Western Europe 1985-1995. European Journal of Education, 30(4), 377-393.

Oomens, M. J. H., \& Bosch, F. A. J. (1999). Strategic Issue Management in Major European Based Companies. Long Range Planning, 32(1), 49-57.

Ozga, J., \& Sukhnandan, L. (2004). Undergraduate Non-Completion: Developing an Explanatory model. Higher Education Quarterly, 52, 316-333.

Pfeffer, J., \& Salancik, G. (1978). The external control of organizations: A resource dependence perspective. New York: Harper \& Row.

Starbuck, W. H. (1965). Organizational Growth and Development. In J. G. March (Ed.), Handbook of Organizations (pp. 451-533). Chicago: Rand-McNally.

Thompson, J., \& Martin, F. (2005). Strategic Management: Awareness and Change. United Kingdom: Cengage Learning EMEA.

Trommel, W., \& Veen, R. van der. (1997). Sociological perspectives on institutions and Neo Institutionalism. In B. Steunenberg, \& F. A. van Vught (Eds.), Political Institutions and Public Policy (pp. 45-66). Dordrecht: Kluwer Academic Publishers.

Trow, M. (1972). The Expansion and Transformation of Higher Education. The International Review of Education, 18(1), 61-84.

Vught, F. A. van. (2011). Responding to the EU innovation strategy. In J. Enders et al. (Eds.), Reform of Higher Education in Europe (pp. 63-80). Rotterdam, Sense Publishers.

Wende, M. C. van der. (2003). Globalisation and Access to Higher Education. Journal of Studies in International Education, 6(3), 1-14.

Wild, L., \& Ebbers, L. (2002). Rethinking Student Retention in Community Colleges. Journal of Research and Practice, 26, 503-519.

Zucker, L. G. (1991). Postscript: micro-foundations of institutional thought. In W. W. Powell \& P. J. DiMagio (Eds.), The New Institutionalism in Organizational Analysis (pp. 103107). Chicago: University of Chicago Press. 